\title{
Strategi Dakwah di Era New Normal
}

\author{
Ach. Baidowi ${ }^{1}$, Moh. Salehoddin ${ }^{2}$ \\ Sekolah Tinggi Ilmu Dakwah dan Komunikasi Islam Al-Mardliyyah, Pamekasan \\ 1achbaidowi16@gmail.com; ${ }^{2}$ sholehraen6@gmail.com
}

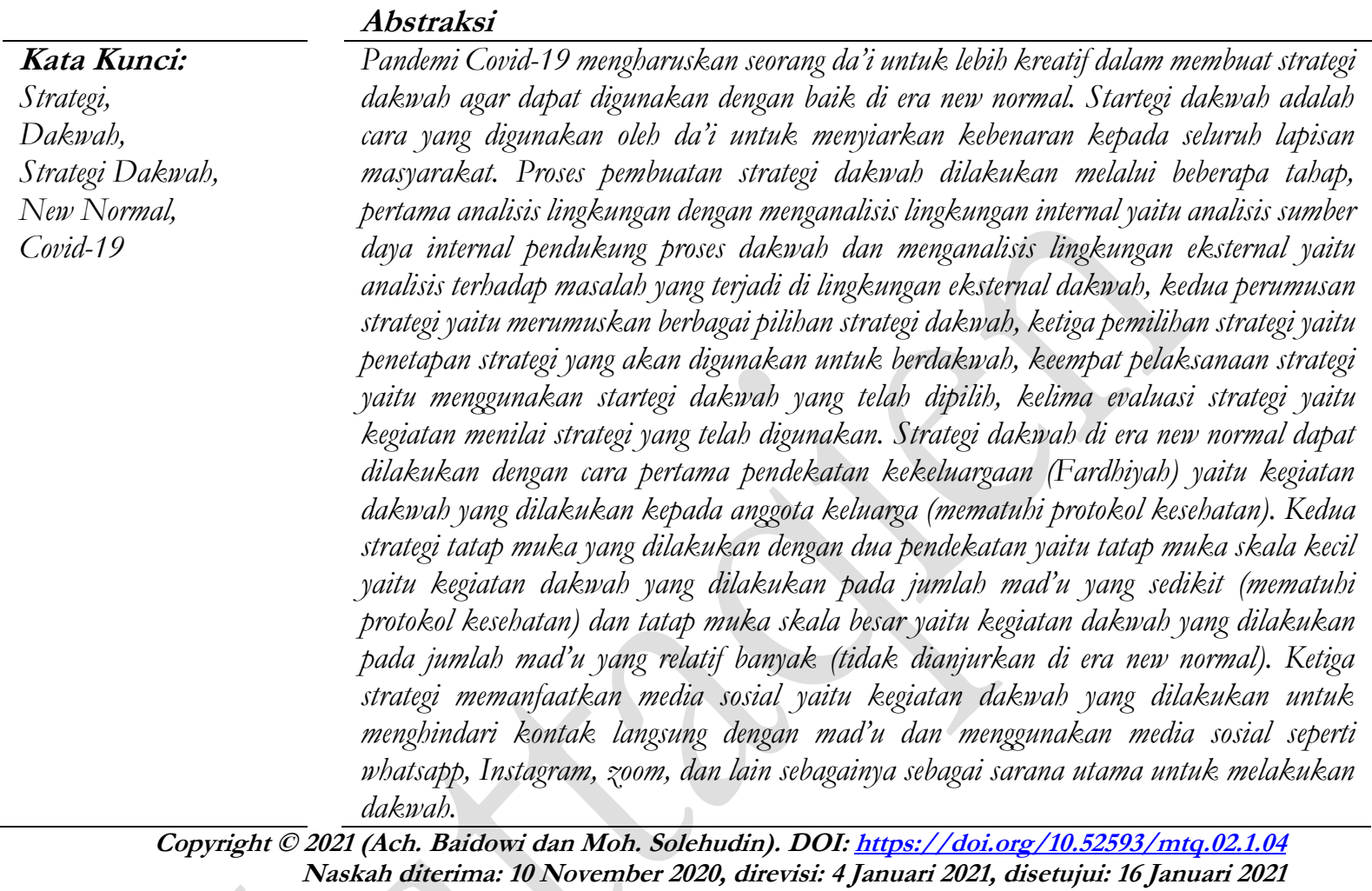

\section{A. Pendahuluan}

Dalam beberapa bulan terakhir, banyak perubahan yang terjadi di Indonesia mulai dari sistem ekonomi, budaya, sampai pada agama yang diakibatkan oleh meluasnya penyebaran virus covid-19. Penyebaran virus corona atau covid-19 yang meluas di Indonesia mengharuskan seluruh masyarakat untuk tidak bepergian atau keluar rumah untuk melakukan pertemuan atau berkumpul dengan orang lain secara langsung. Hal ini dikarenakan dikhawatirkan penyebaran virus covid-19 semakin meluas dan mengakibat orang-orang terjebak pada situasi dan kondisi yang membosankan dengan harus meninggalkan runitas pekerjaan yang sudah sering dilakukan. Kondisi demikian, mengharuskan semua orang untuk mulai berfikir lebih tentang bagaimana cara agar mereka bisa keluar dari kejenuhan dan kebosanan yang mulai melanda kondisi psikis masyarakat.

Edaran yang dikeluarkan oleh pemerintah mengenai Work from Home (WFH) bagi seluruh masyarakat Indonesia termasuk para ulama' yang diharuskan untuk melakukan kegiatan keagamaan termasuk dakwah dan lain-lain sebagainya dari tempat tinggal masingmasing. Umat islam tidak boleh menyelenggarakan shalat jum'at dikawasan tertentu dan juga tidak boleh menyelenggarakan aktivitas ibadah yang melibatkan orang banyak yang diyakini menjadi potensi penyebaran virus covid-19 seperti shalat jum'at, tarawih, serta menghadiri 
pengajian umum (Fatwa MUI No. 14 Tahun 2020). Seorang da’i, di masa pandemi covid-19 banyak diantara mereka tidak dapat melaksanakan tugasnya untuk menyebarkan ajaran agama Islam secara langsung kepada orang lain. Himbauan dari pemerintah untuk tidak keluar rumah dan berkerumun selama pandemi covid-19 mengharuskan seorang da'i untuk dapat berfikir lebih kreatif dalam merumuskan dan memutuskan strategi dakwah yang sesuai dengan kondisi masyarakat khususnya kondisi dakwah di era new normal covid-19 di masa mendatang.

Strategi dakwah adalah usaha yang dilakukan oleh seorang däi untuk tetap bisa melaksanakan dakwah (memberi siraman rohani) di era new normal covid-19. Strategi dakwah yang biasanya dilakukan secara klasik (ceramah secara tatap muka langsung) pada masa pandemi covid-19 menjadikan kegiatan dakwah dilakukan dengan cara modern yaitu dengan memanfaatkan teknologi informasi seperti media sosial, media online, dan media berbasis virtual. Dengan strategi ini memudahkan para da’i dalam hal menyebarkan materi dakwah dengan sangat luas dan memudahkan masyarakat untuk mengakses informasi mengenai ajaran agama Islam.

Berdasarkan uraian di atas, artikel ini ditulis dengan tujuan pertama bahan referensi bagi para da'i dalam merumuskan strategi dakwah yang tepat melalui pendekatan beberapa tahapan perumusan strategi dakwah, kedua sebagai bahan referensi bagi para da'i mengenai pendekatan startegi dakwah yang dapat digunakan di era pandemi covid-19 dan new normal.

\section{B. Teori/ Konsep Strategi}

Strategi merupakan cara yang akan digunakan oleh seseorang atau kelompok untuk melakukan suatau kegiatan atau pekerjaan baik cara tersebut sudah direncanakan atau belum direncanakan sebelumnya (otodidak). Mintzberg, et.al. menyebutkan strategi sebagai usaha yang telah direncanakan oleh seseorang atau organisasi untuk mecapai apa yang mereka inginkan (Aldi, 2015). Dua hal penting dari pengertian tersebut bahwa pertama strategi sebagai usaha, bahwa strategi dakwah yang dibuat oleh seorang da'i berbentuk sebuah usaha dimana usaha tersebut dapat berupa cara, keputusan, program, kebijakan, peraturan, dan lain sebagainya yang dimanfaatkan da'i untuk menyiarkan ajaran agama Islam. Kedua strategi perlu direncakan, strategi dakwah yang direncanakan dengan matang akan sangat bermanfaat bagi seorang da'i dalam hal meminimalisir kesalahan dan resiko saat pengaplikasian strategi dakwah, strategi dakwah yang dibuat dapat berjalan secara terarah, seorang da'i tidak akan mengulangi beberapa tindakan atau aksi terkait dengan pengaplikasian strategi dakwah yang dilakukan, serta memudahkan seorang da'i dalam melakukan evaluasi terhadap strategi dakwah yang telah diaplikasikan.

Henry Mintberg, James Brian Quinn, \& John Voyer mengartikan strategi dalam beberapa perspektif, pertama strategi sebagai perspektif memiliki arti bahwa strategi yang akan dibuat harus berdasarkan pada misi yang diemban oleh seseorang atau organisasi. Kedua strategi sebagai posisi, merupakan kemampuan dari seseorang atau organisasi dalam membentuk dan menempatkan beberapa orang ke dalam beberapa bidang pilihan agar keberadaan mereka dapat diingat oleh orang-orang yang berada di dalam atau di luar organisasi. Ketiga strategi sebagai perencanaan, merupakan proses penyusunan strategi yang 
dilakukan secara sistematik untuk mencapai tujuan yang akan datang dengan berlandaskan pada pertimbangan internal dan eksternal lingkungan organisasi. Keempat strategi sebagai pola kegiatan, yaitu strategi yang dibuat didalamnya berisi suatu pola atau desain terhadap penyelesaian masalah atau pekerjaan yang sedang atau akan dikerjakan. Kelima strategi sebagai rekayasa, strategi merupakan suatu seni untuk mengatur suatu kinerja agar apa yang dilakukan dapat secara berkesinambungan diukur keberhasilan pencapaian tujuannya (Chaniago, 2014).

Berdasarkan penjelasan di atas, maka dapat dijelaskan bahwa startegi dakwah merupakan cara yang digunakan oleh dai'i untuk menyebarluaskan kebenaran kepada sasaran dakwah atau mad'u. Sehingga dapat dijelaskan juga bahwa strategi dakwah di era new normal merupakan proses merumuskan cara yang akan digunakan oleh da’i untuk melakukan dakwah di era new normal nanti. Perumusan strategi dakwah di era new normal dapat dilakukan dengan dua cara, pertama strategi dakwah yang direncanakan, diartikan sebagai sebuah strategi yang dihasilkan dari proses perencanaan dan penganalisaan matang terhadap permasalahan pokok yang sedang dihadapi oleh seseorang atau sekelompok orang pada saat ini yaitu penyebaran virus covid-19 hingga terbentuk suatu startegi dakwah yang tepat untuk digunakan oleh da'i di era new normal. Merencanakan strategi dakwah merupakan proses memikirkan dan mendesain berbagai strategi dakwah yang akan digunakan seorang da'i di era new normal dengan berdasarkan pada permasalahan yang terjadi pada pandemi covid-19. Agar strategi dakwah yang akan digunakan merupakan pilihan yang baik dan tepat, maka diperlukan suatu analisa terhadap strategi dakwah tersebut dengan cara menggali kelebihan dan kelemahan dari strategi dakwah yang telah direncanakan, kemudian dinilai kesesuaian antara strategi dakwah dengan kondisi lingkungan eksternal saat ini (new normal). Mondy \& Premeaux menjelaskan merencanakan sebagai proses mementukan apa yang harus dicapai dan bagaimana cara merealisasikannya dalam kehidupan sehari-hari (Syafaruddin, 2015:69).

Kedua strategi tidak direncanakan merupakan sebuah strategi yang dihasilkan tanpa proses perencanaan strategi sebelumnya. Strategi bentuk ini dapat berupa mencontoh dan memodifikasi startegi yang sudah ada sebelumnya. Mencontoh startegi memiliki arti mengadopsi strategi dakwah yang sudah digunakan oleh orang lain. Sedangkan modifikasi strategi dakwah memiliki arti mengembangkan strategi dakwah milik orang lain atau yang sudah ada sebelumnya dengan cara menambah atau mengurangi beberapa aspek dan/atau kriteria yang terdapat pada startegi dakwah yang dicontohnya agar menjadi strategi dakwah yang bersifat baru sesuai dengan kebutuhan penyelesaian masalah proses dakwah yang dihadapi da'i selama pandemi covid-19 kemarin. Dalam undang-undang pengembangan dijelaskan sebagai suatu proses atau kegiatan memanfaatka ilmu pengetahuan dengan tujuan meningkatkan fungsi dan manfaat dari ilmu pengetahuan tersebut untuk membentuk suatu ilmu pengetahuan dan teknologi yang baru (UU No. 18 Tahun 2002 pasal 1 ayat 5).

\section{Dakwah di Era New Normal}

Kata dakwah secara bahasa diartikan sebagai mengajak dan mempengaruhi orang lain untuk melakukan kabaikan, sedangkan secara terminologi dakwah diartikan sebagai aktivitas mengajak umat Islam untuk mendekati kebaikan dan menjauhi keburukan sesuai ajaran 
agama Islam. Sehinga dapat dijelaskan bahwa dakwah merupakan proses menyampaikan dan menginformasikan kebenaran yang bersumber dari AL-Qur'an dan Al-Hadist kepada seseorang atau sekelompok orang sebagai sasaran dakwah. Dakwah adalah usaha yang dilakukan oleh seorang da'i untuk mengubah keadaan negatif yang terjadi pada orang atau sekelompok orang menjadi keadaan yang positif dengan memperjuangkan yang ma'ruf terhadap kemungkaran serta memenangkan hak atas kebatilan (Aminudin, 2016). Dakwah dapat juga dikatakan sebagai ajakan yang dilakukan oleh da'i kepada mad'u untuk melakukan kebaikan dan menjahui keburukan dengan tujuan untuk mendapatkan kehidupan yang lebih bermanfaat baik di dunia khususnya di akhirat sesuai dengan perintah Allah SWT dan RasulNya. Dakwah pada hakikatnya adalah kewajiban bagi seluruh umat Islam hal tersebut sesuai dengan firman Allah SWT dalam Al-Qur'an surat Saba' ayat 28 yang memiliki arti: Dan kami tidak tidak mengutusmu, melainkan kepada umat manusia selurubnya sebagai pembawa berita gembira dan pemberi peringatan, tetapi kebanyakan dari mereka tidak ada yang mengetabuinya (Aminudin, 2016). Surat tersebut menjelaskan bahwa setiap umat manusia baik itu muslim ataupun nonmuslim memiliki kewajiban yang sama dalam kehidupannya yaitu menyiarkan kebenaran dan memperingatkan umat manusia untuk melakukan kebenaran sesuai dengan perintah Allah SW'T agar tidak terjerumus kepada jalan keburukan. Pernyataan tersebut mengisyaratkan bahwa dakwah di era new normal dilakukan kepada seluruh lapisan masyarakat baik muslim ataupun non-muslim agar tetap waspada terhadap penyebaran virus covid-19 dengan materi dakwah yang dapat disampaikan seperti kebersihan dalam Islam, menjaga kesehatan dalam Islam, atau bahkan materi tentang tindakan tidak merugikan orang lain menurut Islam.

Fungsi dakwah di era new normal adalah sebagai sarana bagi seorang da'i untuk menyebarkan dan menyiarkan kebenaran tentang pentingnya mematuhi protokol kesehatan di era new normal dari pandangan agama Islam kepada seluruh umat. Menyebarkan ajaran Islam kepada orang atau sekelompok orang yang menjadi sasaran dakwah, membudayakan dan melestarikan nilai yang terkandung dalam agama Islam pada generasi berikutnya, serta untuk meluruskan akhlaq yang tidak baik yang dapat membantu umat manusia keluar dari kegelapan secara bathiniyah (Hasan, 2013:47). Tujuan dakwah di era new normal adalah untuk memperingati dan menyadarkan umat Islam secara kesuluruhan agar mereka dapat waspada akan penyebaran virus covid-19 dan tetap menjalankan protokol kesehatan yang telah dianjurkan oleh pemerintah sesuai dengan syariat Islam. Tujuan dakwah meningkatkan kualitas iman dan taqwa umat muslim secara menyeluruh, menyiarkan kebaikan dan mencegah keburukan yang dapat meruntuhkan nilai-nilai Islam dalam kehidupan umat muslim, serta dapat menjadikan Islam sebagai dasar pegangan dan pandangan hidup bagi seluruh umat manusia (Hasan, 2013:49). Tujuan tersebut ssuai dengan yang dijelaskan dalam AL-Qur'an surat An-Nahl ayat 125 yang artinya: Serulah (manusia) kepada jalan Tuhan-mu dengan bikmah dan pelajaran yang baik dan bantablah mereka dengan cara yang baik. Sesunggubnya Tuban-mu yang lebih mengetahui tentang siapa yang tersesat dari jalan-Nya dan lebih mengetahui orang-orang yang mendapat petunjuk (Mutiawati, 2018). 


\section{Unsur Dakwah}

Unsur diartikan sebagai bagian atau aspek-aspek yang secara langsung atau tidak langsung dapat mempengaruhi suatu pekerjaan/kegiatan. Maka berdasarkan hal tersebut, unsur-unsur dalam dakwah dapat dijelaskan seperti gambar berikut:

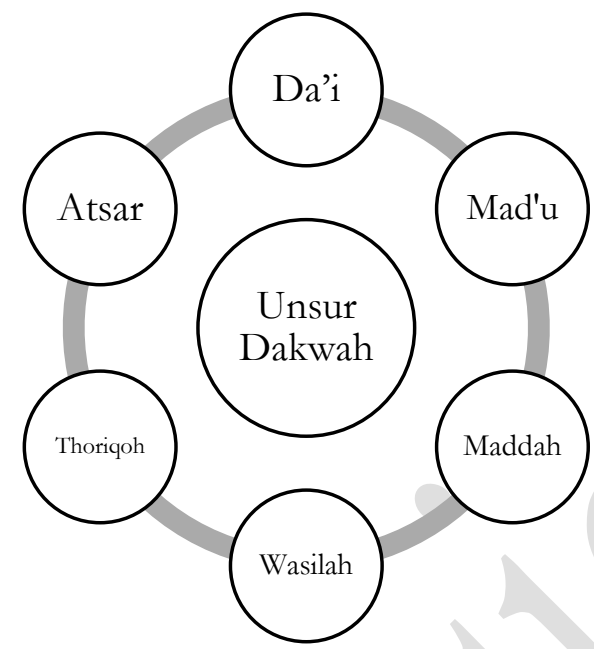

\section{Gambar 1. Unsur-Unsur Dakwah}

Sumber: Penulis

Berdasarkan gambar 1, maka unsur-unsur yang terdapat dalam kegiatan dakwah dapat dijelaskan sebagai berikut:

a. Pelaku Dakwah (Da' $)$

Da'i adalah orang yang melakukan dakwah, artinya seseorang yang bertugas menyampaikan kebenaran yang bersumber dari Al-Qu'an dan Al-Hadist kepada sasaran atau objek dakwah baik secara lisan atau tulisan. Da'i adalah seseorang yang mengemban misi untuk menyerukan ajaran agama Islam kepada sasaran dakwah (Risdiana, 2014). Da`i di era new normal tidak hanya dilakukan oleh ahli agama yang telah memahami bahaya penyebaran Covid-19, tetapi juga dapat dilakukan oleh dokter, petugas Satgas Covid-19, atau bahkan masyarakat untuk selalu menjaga kesehatan dan mematuhi anjuran kesehatan yang telah ditetapkan pemerintah. Seorang dä $i$ harus mampu mengetuk dan membuka hati para sasaran dakwah untuk ikut bersama-sama menjaga kesehatan dengan tujuan mencegah penyebaran virus Covid-19 serta senantiasa mendekatkan diri kepada Yang Maha Kuasa agar terhindar dari bahaya virus Covid-19.

b. Sasaran Dakwah (Mad'u)

Sasaran dakwah atau dalam Bahasa arab disebut dengan Mad'u adalah orang baik yang bersifat perorangan atau kelompok yang menjadi objek dakwah. Sasaran dakwah juga dapat diartikan sebagai sekumpulan orang yang menyimak (mendengarkan) apa yang disampaikan oleh seorang da'i dan membaca apa yang ditulis oleh da'i. Mad'u adalah seluruh orang baik bergama muslim ataupun nonmuslim yang menjadi objek dakwah (Aminudin, 2016). Sasaran dakwah dapat dikelompokkan menjadi dua, pertama sasaran dakwah non-muslim, dimana dakwah 
dilakukan dengan tujuan untuk mengajak umat non-muslim untuk ikut mempelajari atau bahkan mengikuti ajaran agama Islam. Berdasarkan pernyataan tersebut, sasaran dakwah di era new normal adalah seluruh lapisan masyarakat baik muslim ataupun non-muslim baik yang sehat ataupun yang sedang dan sudah terpapar virus Covid19.

c. Materi Dakwah (Maddab)

Materi merupakan bahan tertulis maupun tidak tertulis yang digunakan oleh seseorang untuk membantu proses pembelajaran dalam suatu lingkungan pembelajaran (Ahmadi, Amri \& Elisah, 2011:208). Materi dakwah merupakan sekumpulan informasi yang berisi gagasan atau ide tentang kebenaran dan larangan yang besumber dari Allah SWT untuk disampaikan kepada seluruh umat manusia. Seorang da'i harus dapat menyusun materi dakwah dengan baik, sistematis, dan mudah dipahami oleh seluruh sasaran dakwah. Materi dakwah yang akan disampaikan harus sesuai dengan situasi dan kondisi sasaran dakwah saat ini. Materi disusun secara sistematis memiliki arti materi harus tersusun secara berurutan mulai dari materi pendahuluan, materi inti, dan materi penutup sesuai dengan pokok pembahasan yang akan disampaikan. Sedangkan materi yang mudah dipahami adalah materi yang isinya mudah diingat, mudah dimengerti dan dapat memberikan efek yang positif terhadap perubahan sikap dan perilaku mad'u setelah menerima materi dakwah.

Berdasarkan hal tersebut, materi dakwah di era new normal dapat dibedakan menjadi dua yaitu pertama berdasarkan pada sasaran dakwah yang negatif terpapar virus Covid-19 dimana materi dakwah dapat berisi tentang ajakan atau seruan untuk selalu menjaga kesehatan menurut Islam, menjaga kebersihan menurut Islam, mengikuti protokol kesehatan dari pemerintah menurut pandangan Islam, serta materi-materi lain yang dapat meningkatkan keimanan dan ketaqwaan kepada Allah SW'T di era new normal. Kedua berdasarkan pada sasaran dakwah yang positif terpapar covid-19 dimana materi dakwah yang dapat diserukan seperti materi tentang kesabaran, keikhlasan menghadapi cobaan dan/atau bahkan materi yang dapat mendekatkan diri kepada Allah pada masa-masa sulit yang sedang dihadapi oleh sasaran dakwah. Materi adalah pengetahuan, keterampilan serta sikap yang harus dikuasi oleh seseorang sehingga untuk mendukung tercapainya standart kompetensi dan indikator keberhasilan tujuan yang telah ditentukan oleh pembuat materi (Churri \& Agung, 2013).

Sumber materi dakwah di era new normal berasal dari dua sumber utama, pertama Al-Qur'an dan Al-hadis, Al-Qur'an merupakan kalamullab yang diyakini tingkat kebenarannya sangat tinggi bagi seluruh umat muslim, sedangkan Al-Hadist merupakan kitab yang berisi tentang perkataan dan perbuatan sholeh yang dicontohkan oleh Nabi Muhammad SAW yang dijadikan landasan kedua dalam menyerukan ajaran agama Islam. Tentang sumber materi dakwah ini seperti yang sudah dijelaskan dalam kitam Al-Qur'an surat Al-Maidah ayaut 16 yang artinya: Dengan kitab itulah Allab memberikan petunjuk kepada orang yang mengikuti keridhaan-Nya ke jalan keselamatan, dan (dengan Kitab itu pula) Allah mengeluarkan orang itu dari gelap gulita kepada cahaya dengan izin-Nya dan menunjukkan ke jalan yang lurus (Hidayat \& Andira, 
2019). Kedua pemerintah, yaitu materi dakwah yang berkaiatan dengan menjaga kesehatan melalui protokol kesehatan yang telah ditetapkan oleh pemerintah yang dapat dipadupadankan dengan pandangan Islam tentang menjaga kesehatan di era new normal.

d. Metode Dakwah (Thoriqoh)

Metode dapat diartikan sebagai teknik yang digunakan seseorang untuk menyelesaikan suatu pekerjaan atau permasalahan. Metode dakwah adalah teknik yang digunakan oleh da $i$ dalam menyampaikan materi dakwah dengan harapan apa yang disampaikan dapat diterima dengan baik oleh mad'u. Metode merupakan teknik yang dibuat secara prosedural (melalui beberapa tahapan) oleh seseorang dan digunakan untuk menyelesaikan dan mencapai tujuan yang telah ditetapkan (Pane \& Dasopang, 2017). Teknik dahwah di era new normal dapat dilakukan dengan pendekatan ceramah untuk menghindari kontak langsung dan menjaga jarak dengan sasaran dakwah untuk menghindari penularan dan penyebaran virus Covid-19.

Seorang $d a^{\prime} i$ dalam proses perumusan metode dakwah perlu memperhatikan beberapa aspek mad'u, maddah, dan wasilah. Aspek mad'u, seorang da'i perlu memperhatikan jenis dan jumlah sasaran dakwah yang akan dihadapinya di era new normal. Sasaran dakwah yang didominasi oleh anak-anak atau remaja tentunya metode dakwah yang digunakan akan berbeda ketika seorang $d a^{\prime} i$ berhadapan dengan orang dewasa. Begitu juga dengan jumlah sasaran dakwah, di era new normal sorang da'i wajib mengetahui bahwa dia akan berdakwah dimana, dengan siapa, dan berapa jumlah pesertanya karena hal tersebut sangat mempengaruhi seorang da'i dalam memutuskan metode dakwah yang tepat untuk digunakan di era new normal nanti. Aspek maddah atau materi sangat mempengaruhi terhadap pemilihan metode dakwah. Materi dakwah yang ringan, membutuhkan metode dakwah yang tidak terlalu berat atau tidak berlebihan, dan begitu juga sebaliknya. Sedangkan aspek wasilah atau media merupakan peralatan yang keberadaannya dapat mendukung dan mempermudah däi dalam melaksanakan dakwah yang akan diaplikasikan di era new normal.

e. Media Dakwah (Wasilah)

Media adalah peralatan yang digunakan oleh seseorang atau organisasi untuk mendukung terlaksananya suatu pekerjaan yang akan dikerjakan. Media dakwah merupakan seperangkat peralatan yang digunakan oleh da'i untuk mendukung proses pelaksanaan dakwah di era new normal seperti buku, perangkat keras atau perangkat lunak IT, peralatan pendukung protokol kesehatan dan lain sebagainya. AECT (Association of Education and Communication Technology) menjelaskan media merupakan segala sesuatu (berbentuk peralatan) yang dimanfaatkan oleh seseorang untuk membantu dan mempermudah proses menyampaikan pesan atau informasi kepada orang lain (Tafonao, 2018). Media terdiri atas beberapa unsur orang, teknologi, sarana, peralatan dan lain sebagainya yang disusun secara rapi untuk membentuk suatu proses komunikasi yang sistematis dalam pembelajaran (Mahnun, 2012).

Berdasarkan pernyataan di atas, dapat dijelaskan bahwa media dalam pelaksanaan dakwah di era new normal terdiri atas beberapa peralatan yang saling 
menguntungkan satu sama lain dimana peralatan-peralatan tersebut sengaja dipersiapkan oleh seorang $d a^{\prime} i$ untuk mendukung proses komunikasi selama kegiatan dakwah berlangsung. Dengan penggunaan media dakwah yang tepat di era new normal selain untuk menghindari diri dari penyebaran virus Covid-19, seorang däi juga dapat dengan aman dan mudah menyampaikan materi dakwah kepada seluruh sasaran dakwah (mad'u) sehingga dapat menciptakan suasana dakwah yang lebih menarik dan tidak membosankan.

f. Dampak Dakwah (Atsar)

Dampak dakwah adalah efek yang ditimbulkan dari suatu kegiatan terhadap sikap dan perilaku seseorang atau sekolompok orang yang menjadi objek suatu kegiatan. Dampak dakwah dapat diartikan sebagai pengaruh yang diterima oleh mad'u dari kegiatan dakwah. Pengaruh, berarti kegiatan dakwah tersebut harus mampu mempengaruhi pikiran, sikap, dan perilaku mad'u untuk tetap berada di jalan Allah SWT. Dampak berkaiatan dengan proses berubahanya pengetahuan, keterampilan, dan kepercayaan seseorang yang timbul akibat adanya informasi (Hasan, 2013:85). Sehingga dapat dijelaskan bahwa dampak dakwah di era new normal ialah diharapkan masyarakat mampu memahami dan sadar akan pentingnya menjaga kesehatan diri, serta mampu memberikan perubahan yang positif terhadap sikap, perilaku, dan pengetahuan mad'u untuk tetap menjaga diri dari penyakit (virus) dan menjaga diri untuk tidak melakukan tindakan yang merugikan orang lain.

\section{Metode Penelitian/Metode Kajian}

Metode yang dilakukan dalam melakukan penelitian ini adalah kualitatif deskrptif dengan pendekatan kajian konten/ kepustakaan. Adapun sumber dalam penelitian ini adalah kajian ayat Al-Qur'an surat Saba' ayat 28 dan Al-Qur'an surat An-Nahl ayat 125 dengan menggunakan analisa teori Henry Mintberg, James Brian Quinn, \& John Voyer tentang strategi.

\section{Hasil dan Pembahasan}

\section{Proses Pembuatan Strategi Dakwah}

Proses pembuatan strategi merupakan tahapan pembuatan berbagai rencana atau cara yang akan digunakan oleh seseorang atau organisasi dalam mencapai tujuan yang mereka inginkan. Tidak terkecuali dengan dakwah khususnya di era new normal nanti yang memerlukan beberapa strategi dalam pelaksanaannya agar apa yang disampaikan oleh da'i dapat tersampaikan dan dicerna dengan sangat baik oleh sasaran dakwah. Proses pembuatan startegi dakwah terdiri atas beberapa tahap yang dapat dijelaskan sebagai berikut:

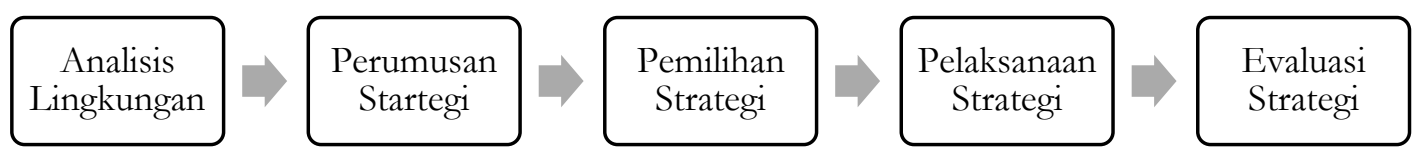

Gambar 2. Proses Pembuatan Strategi Dakwah

Sumber: Penulis 
1. Analisis Lingkungan Dakwah

Analisis lingkungan merupakan kegiatan mengenali dan menggali lebih dalam terhadap kondisi internal dan eksternal tempat seorang da'i berada. Analisis dilakukan untuk mengetahui masalah atau isu yang terjadi pada lingkungan eksternal dan menggali lebih dalam tentang sumber daya yang dimiliki oleh da’i demi terbentuknya suatu strategi dakwah yang efektif dan efisien untuk digunakan di era new normal nanti. Alat yang dapat digunakan untuk menganalisis lingkungan da'i tersebut dapat dilakukan dengan pendekatan analisis SWOT yaitu suatu analisis terhadap kelebihan dan kelemahan lingkungan internal dakwah, dan analisis terhadap peluang dan ancaman lingkungan eksternal dakwah yang dapat dijelaskan dalam tabel berikut:

Tabel 1. Matriks Analisis SWOT

\begin{tabular}{|c|c|c|}
\hline Eksternal & \multirow{2}{*}{$\begin{array}{c}\text { Opportunity } \\
\text { (Peluang) }\end{array}$} & $\begin{array}{c}\text { Treaths } \\
\text { (Ancaman) }\end{array}$ \\
\hline Strength (Kekuatan) & SO? & ST? \\
\hline Weakness (Kelemahan) & WO? & WT? \\
\hline
\end{tabular}

Sumber: Chaniago, Siti Aminah (2014)

Jurnal Hukum Islam, Vol. 12 No. 1

Berdasarkan tabel 1, analisis lingkungan dakwah dibagi atas dua analisis, yaitu analisis lingkungan internal eksternal dakwah yang dapat dijelaskan sebagai berikut:

a. Analisis Lingkungan Internal Dakwah

Analisi lingkungan internal adalah proses mengidentifikasi dan menggali secara lebih dalam kekuatan dan kelemahan yang dimiliki organisasi dan berpengaruh terhadap proses pengambuilan keputusan oleh seorang pemimpin organisasi (Adjibroto, Kaizer \& Priggabayu, 2018). Sehingga dapat dijelaskan bahwa analisis lingkungan internal dakwah di era new normal merupakan kegiatan melihat dan menilai kondisi internal da'i yang dapat mempengaruhi terbentuknya strategi dakwah. Melihat, diartikan sebagai analisis terhadap keberadaan sumber daya yang dimiliki oleh da'i untuk membantu melaksanakan dakwah di era new normal. Strength-opportunity strategic dilakukan dengan memanfaatkan seluruh kekuatan yang diimiliki oleh seseorang atau organsiasi untuk memanfaatkan peluang yang ada secara maksimal (Rangkuti, 2013:19). Sedangkan menilai lingkungan internal dä yaitu menganalisis kebermanfaatan atau nilai guna terhadap sumber daya yang dimiliki seorang da'i untuk mendukung pelaksanaan dakwah yang efektif dan efisien di era new normal nanti. Efektif diartikan sebagai strategi dakwah dapat digunakan pada situasi dan kondisi yang berbeda-beda, sedangkan efisien diartikan sebagai strategi dakwah yang digunakan tidak memerlukan waktu, dana, dan tenaga yang banyak. Strength-threath strategic pemanfaatan 
kekuatan yang dimiliki oleh seseorang atau organisasi untuk mencegah segala bentuk ancaman yang datang dari lingkungan eksternal (Rangkuti, 2013:19).

b. Analisis Lingkungan Eksternal Dakwah

Analisis lingkungan eksternal adalah kegiatan mengidentifikasi faktor-faktor ancaman dan peluang yang terjadi di luar lingkungan internal dan berpengaruh terhadap pengambilan keputusan dalam organisasi (Adjibroto, et.al, 2018). Analisis lingkungan eksternal dakwah di era new normal merupakan kegiatan melihat dan menilai masalah-masalah yang terjadi pada lingkungan eksternal yang secara langsung ataupun tidak langsung dapat mempengaruhi proses dakwah. Pertama melihat berarti menganalisis isu atau masalah atau ancaman yang terjadi pada lingkungan eksternal dakwah dan memiliki pengaruh langsung terhadap kondisi internal dakwah. Penyebaran virus Covid-19 yang meluas dilingkungan masyarakat melumpuhkan seluruh kegiatan diberbagai sektor publik ataupun pendidikan, tidak terkecuali dengan bidang keagamaan. Banyak orang yang tidak dapat melakukan ibadah di tempat ibadah sebagai mana mestinya, banyak da'i yang tidak dapat melakukan dakwah secara langsung dengan orang lain, hal ini tentunya berdampak pada pola perilaku dan berfikir seorang da'i untuk tetap bisa melakukan dakwah di masa pandemi atau new normal nanti. WeaknessThreath Strategic seseorang atau organisasi dapat meminimalkan kekurang atau kelemahan yang dimilikinya untuk menghindari berbagai ancaman atau permaslaahan yang terjadi dilingkungan eksternal (Rangkuti, 2013:19). Kedua menilai berarti mengevaluasi isu atau masalah atau ancaman yang terjadi pada lingkungan eksternal dengan tujuan memperoleh kesempatan atau peluang bagi seorang da'i dalam membentuk sebuah strategi dakwah yang dapat aplikasikan dalam berbagai situasi. Perubahan perilaku masyarakat di era new normal dan perubahan cara berfikir seorang da'i untuk merumuskan startegi dakwah yang tepat di era pandemi dan new normal nanti, menandakan bahwa seorang da'i sudah dapat memahami ancaman dan memanfaatkan peluang yang terjadi di lingkungan masyarakat. Weakness-opportunity strategic dengan memanfaatkan peluang yang ada di lingkungan eksternal dengan cara meminimalkan kelemahan yang dimiliki (Rangkuti, 2013:19). Hal ini mengisyarakatkan bahwa seorang $d a^{\prime} i$ harus dapat membaca peluang dengan cara menganalisis apa saja yang dapat digunakan dan hal-hal apa saja yang dapat dilakukan untuk membentuk suatu strategi dakwah yang sesuai dengan situasi dan kondisi internal dan eksternal pada saat ini (pandemi Covid-19) dan mendatang (era new normal).

\section{Perumusan Strategi Dakwah}

Tahap ini diartikan sebagai perumusan berbagai strategi yang "mungkin" akan digunakan oleh da'i di era new normal nanti. Tahap ini indentik dengan perumusan beberapa pilihan strategi dakwah yang akan digunakan untuk kegiatan dakwah. Pada tahap ini seseorang akan berusaha mengumpulkan berbagai strategi dimana masing- 
masing strategi yang dkumpulkant memiliki peluang yang sama untuk dipilih dan digunakan oleh pembuat strategi, semakin banyak pilihan strategi akan memudahkan seseorang dalam memilih salh satu dari strategi yang dikumpulkan (Suharno, Sudibyo, et.al., 2014). Seorang da'i dapat membuat list strategi dakwah dengan mengurutkan beberapa strategi dakwah mulai dari startegi yang paling mudah sampai pada strategi dakwah yang sulit untuk digunakan di era new normal nanti. Pada daftar strategi yang telah disusun, da'i dapat memberikan analisis terhadap masing-masing strategi dengan cara menilai kelebihan dan kekuarang dari masing-masing startegi yang telah disusun. Dengan cara tersebut da'i dapat memilih dan memutuskan strategi mana yang tepat untuk digunakan untuk berdakwah di era new normal. Woll menjelaskan formulasi merupakan tahap dimana para analis mulai menjustifikasi beberapa kebijakan atau keputusan yang dibuat bahwa pilihan dari suatu kebijakan atau keputusan merupakan pilihan terbaik dari sekian banyak kebijakan atau keputusan yang ada (Anggara, 2014:184).

3. Pemilihan Strategi Dakwah

Tahap ini diartikan sebagai proses penetapan dan memutuskan strategi dakwah yang akan digunakan oleh da'i selama kegiatan dakwah akan dilaksanakan. Tahap ini adalah proses penyesuaian dan penerimaan terhadap keputusan yang telah diakui kebenarannya (Anggara, 2014:184). Berdasarkan hasil analisis terhadap kumpulan startegi dakwah yang telah dilakukan, kemudian da’i dapat memilih dan memutuskan strategi dakwah yang tepat untuk digunakan pada era new normal nanti. Pilihan startegi dakwah yang tepat adalah pilihan strategi yang sesuai dengan situasi dan kondisi lingkungan internal dan eksternal dakwah. Pemilihan strategi sebagai langkah merekapitulasi strategi mana saja yang akan digunakan oleh pembuat strategi dari kumpulan strategi yang telah dibuat sebelumnya (Suharno, Sudibyo, et.al., 2014).

\section{Penggunaan Strategi Dakwah}

Tahap ini merupakan tahap menggunakan atau memanfaatkan strategi dakwah yang telah dipilih oleh da'i pada proses pemilihan strategi dakwah. Menggunakan memiliki arti menerapkan apa yang telah ditetapkan, sehingga seorang da'i sudah mulai menerapkan atau mengaplikasikan strategi dakwah yang telah dibuat dengan baik sesuai dengan persiapan yang telah ditentukan sebelumnya. Sehingga dapat dijelaskan bahwa menggunakan strategi dakwah di era new normal nanti adalah proses memanfaatkan strategi yang didukung dengan penggunaan media atau peralatan yang telah disiapkan däi sebelumnya. Menggunakan atau mengimplementasikan keputusan terjadi pola interaksi antara pembuat keputusan dengan cara mendorong, mempengaruhi dan merangsang sasaran untuk turut serta melakukan apa yang dibuat atau diinteruksikan oleh pembuat keputusan (Arwildayanto, Suking \& Sumar, 2018:78). Strategi dakwah yang digunakan oleh da’i harus mampu mempengaruhi dan mengajak sasaran dakwah supaya mereka secara 
bersama-sama senantiasa melakukan kebaikan bagi sesama umat manusia khususnya di masa penyebaran virus Covid-19 dan tetap berada di jalan Allah SWT.

\section{Evaluasi Strategi Dakwah}

Tahap ini merupakan tahap memberi penilaian terhadap strategi dakwah yang telah diaplikasikan. Evaluasi sebagai proses yang direncakan untuk mengumpulkan informasi tentang tindakan yang telah dilakukan sehingga dapat disusun suatu penilaian untuk membentuk keputusan terhadap tindakan yang telah dievaluasi (Sawaluddin, 2018). Evaluasi strategi dakwah dapat dilakukan dengan menilai dampak strategi dakwah terhadap proses dan hasil pelaksanaan dakwah. Dampak terhadap proses dakwah, dapat dilihat dari sejauh mana strategi yang digunakan dapat secara penuh mendukung proses penyampaian materi dakwah. Sedangkan dampak terhadap hasil dakwah yaitu dengan melihat sejauh mana strategi yang digunakan dapat mempengaruhi sasaran dakwah sehingga mereka dapat memahami dan mengaplikasikan materi dakwah yang telah disampaikan. Evaluasi diambil dari kata al-hisab, al-bala, dan fatanna yang memiliki arti evaluasi dilakukan untuk mengukur amal jariyah manusia dan dari kata imti-an atau khataman yang berarti melihat hasil akhir dari suatu kegiatan (Ramadhani, Nahar \& Syaukani, 2018). Sehingga dapat dijelaskan bahwa evaluasi dapat dijelaskan sebagai proses menilai dan mengukur sejauh mana keputusan yang diaplikasikan dapat menumbuhkan hasil sesuai dengan yang diharapkan oleh pembuat keputusan (Arwildayanto, et.al., 2018:103).

\section{Strategi Dakwah Di Era New Normal}

1. Strategi Pendekatan Keluarga (Fardhiyah)

Strategi dakwah pendekatan keluarga merupakan strategi menyampaikan dan menginformasikan ajaran agama Islam yang dilakukan oleh da'i kepada anggota keluarga sendiri, kerabat dekat, atau anggota keluarga lainnya. Pendekatan family gatering merupakan suatu pendekatan keluarga yang bertujuan untuk membangun kerjasama yang baik antar masing-masing anggota keluarga serta terjalinnya suatu komunikasi tanpa ada batasan umur dan status antar anggota keluarga (Miharja \& Syamsuddin, 2018). Strategi ini merupakan strategi dakwah paling dasar (karena skalanya sangat kecil) dan paling efektif digunakan oleh seorang da'i untuk tetap melaksanakan kewajibannya sebagai seorang penyiar atau penyampai ajaran agama Islam di masa pandemi covid-19 serta new normal. Jumlah mad'u yang relatif sedikit pada pendekatan ini memungkinkan seorang da'i untuk tetap melakukan kewajibannya sebagai pendakwah untuk orang lain.

Strategi dakwah ini di era new normal dapat digunakan seorang da'i dengan memberikan siraman rohani pada anggota keluarganya tanpa ada batasan waktu, namun tetap ada batasan jarak dan jumlah mad'u yang sesuai dengan aturan protokol kesehatan dari pemerintah. Strategi dakwah pendekatan keluarga dilakukan dengan memberikan nasihat, peringatan, atau bahkan pengaruh kepada anggota keluarga dengan tujuan memperbaiki perilaku dan sikap/akhlaq orang lain terhadap penyebaran virus Covid-19, meningkatkan iman dan taqwa kepada Allah SWT, serta 
meningkatkan kecintaannya terhadap Nabi Muhammad SAW. Dakwah dengan pendekatan keluarga yaitu dengan menjadikan diri sendiri dan keluarga sebagi sendi atau fokus utama dalam pelaksanaan dakwah yang dapat dilakukan dengan meningkatkan fungsi orang tua sebagai sosok tauladan bagi seluruh anggota keluarganya seperti anak, suami atau istri, dan lain sebagainya (Abzar, 2015).

\section{Strategi Tatap Muka}

Strategi tatap muka merupakan startegi dakwah yang paling sering dilakukan yaitu dilakukannya pertemuan langsung antara da'i dengan mad'u yang dilakukan dalam suatu tempat yang telah dipersipakan. Face to face learning was carried out by visiting students house yang memiliki arti bahwa pembelajaran secara tatap muka selama masa pandemi covid-19 dilakukan dengan cara guru mengunjungi rumah siswa secara langsung (Baidowi, 2020). Hat tersebut menjelaskan bahwa strategi dakwah secara tatap muka merupakan startegi mengunjungi mad'u secara langsung untuk diberikan pencerahan. Startegi ini dinilai paling efektif bagi da’i karena sejatinya dakwah adalah memberikan nasihat dan pengetahuan tentang ajaran Islam dengan tujuan mengubah sifat, sikap, dan perilaku seseorang atau sekelompok orang yang jika dilakukan secara langsung da'i dapat melihat dampak serta perubahan yang terjadi kepada mad'u. Metode tatap muka merupakan metode yang dilakukan dengan cara bertemu langsung dengan objek pembelajaran, dimana dalam metode ini terdapat unsur tenaga pendidik dan orang yang di didik yang saling berinteraksi dengan baik dalam pemberian materi ataupun tanyajawab dalam suatu tempat (Silitonga \& Eminency, 2012). Strategi dakwah ini dalam masa pandemi covid-19 dan new normal dapat dilakukan dengan dua cara sebagai berikut:

a. Tatap Muka Skala Kecil

Tatap muka ini biasanya dilakukaan ketika jumlah objek atau sasaran dakwah relatif sedikit. Penyebaran virus Covid-19 yang meluas mengharuskan seluruh orang untuk tidak berkerumun dan menjaga jarak, tidak terkecuali dengan pelaksanaan dakwah. Di masa pandemi jumlah sasaran dawak (jamaah dakwah) sangat dibatasi keberadaannya, hal ini dilakukan agar penyebaran virus Covid-19 tidak semakin meluas. Sehingga seorang dai'i harus dapat mengontrol jumlah mad'u yang ingin mengikuti dakwahnya secara langsung. Startegi dakwah ini juga sering dikaitkan dengan strategi pendekatan keluarga karena jumlah mad'u yang sangat sedikit, sehingga seorang da'i dapat menggunakan strategi pendekatan keluarga untuk menyampaikan materi dakwah. Perbedaannya adalah pendekatan keluarga (Fardhiyah) lebih sering digunakan dan dilakukan kepada anggota keluarga atau orang terdekat, sedangkan tatap muka skala kecil digunakan kepada orang atau sekolampok orang yang bukan anggota keluarga dengan jumlah mad'u yang sedikit seperti anggota majelis masjid, komunitas, dan lain sebagainya.

Pendekatan yang dapat dilakukan untuk menggunakan startegi ini di era new normal pertama dengan kesadaran diri sendiri, artinya seorang da'i atas 
kesadaran dirinya memberikan dakwah kepada anggota keluaraga sendiri sehubungan dengan permasalahan yang terjadi pada lingkungan sosial saat ini. Kedua dengan mengumpulkan beberapa orang misalnya anggota keluarga, kerabat dekat, tetangga untuk diberikan tausiah ke-Islam-an. Cara ini biasanya dilakukan oleh seorang kiyai, ustad dan ustadzah dengan cara mengumpulkan beberapa santri atau murid untuk diberikan ilmu tentang keagamaan. Ketiga menghadiri majelis taklim yang jumlah pesertanya sedikit misalnya pengajian di musholla atau tempat lain yang berukuran kecil untuk menghindari kerumunan dan penyebaran virus Covid-19.

b. Tatap Muka Skala Besar

Strategi dakwah yang mempertamukan da'i dengan mad'u dalam suatu pertemuan (acara) yang besar (biasanya diikuti oleh orang banyak tanpa ada batas peserta yang ingin mengikuti dakwah). Strategi ini digunakan pada acara-acara pengajian yang diselenggarakan dengan skala besar seperti tabligh akbar, pernikahan, peringatan Maulid Nabi Muhammad SAW, dan lain sebagainya. Pada masa pandemi covid-19, startegi ini sangat tidak disarankan dan bahkan tidak digunakan oleh seluruh da'i demi keselamatan seluruh umat manusia dari penyebaran virus covid-19. Tatap muka skala besar pada masa pendemi covid-19 dan era new normal dapat dilakukan melalui startegi pemanfaatan media sosial yang menyediakan layanan video streaming dan virtual meeting yang dapat diakses oleh banyak orang. Sehingga seorang da'i tetap dapat memenuhi kewajibannya untuk menyiarkan ajaran Islam dengan bertatap muka langsung melalui dunia maya dengan mad'u meskipun dalam jarak yang berbeda.

\section{Strategi Pemanfaatan Sosial Media}

Masa pandemi covid-19 yang mengharuskan seluruh orang termasuk da’i untuk tetap tinggal atau berada di dalam rumah untuk menghindari kerumunan sehingga mengharuskan seorang da'i membuat suatu strategi dakwah yang bersifat baru untuk menghadapi masa pandemi pada saat ini dan mendatang. Strategi dakwah yang dapat dilakukan pada masa pandemi ataupun new normal nanti untukmmenghindari kerumunan dan kontak langsung dengan mad'u adalah dengan memanfaatkan media sosial sebagai sarana utama untuk menyiarkan kebenaran berdasarkan ajaran Al-Qur'an dan Al-Hadist. Media sosial diartikan sebagai alat komunikasi yang digunakan oleh seseorang untuk berkomunikasi dengan orang lain pada lingkungan sosial (Mulawarman \& Nurfitri, 2017). Media sosial adalah perangkat lunak yang berfungsi sebagai tempat untuk berkumpul, berkomunikasi, dan berbagi antara individu dengan individu yang lain atau antara komunitas dengan komunitas lain (Sari, Hartina, Awalia, et.al., (2019).

Sehingga dapat dijelaskan bahwa media sosial adalah suatu media yang berfungsi sebagai penyampai informasi baik secara tertulis atau non-tertulis (gambar dan video) kepada orang lain yang jumlah pembuat dan penerima pesannya relatif banyak seperti media sosial 
whatapp, facebook, instagram, zoom, dan lain sebagainya. Pengguna sosial media yang mendunia, sangat membantu para da'i untuk menyebarkan dan menyiarkan ajaran Islam kepada banyak orang diberbagai belahan dunia. Pada era digital ini dan new normal nanti, seorang $d a^{\prime} i$ dapat melalukan dakwah secara lisan dan tatap muka melalui layanan siaran streaming, virtual meeting, serta layanan lainnya yang terdapat pada platform media sosial dengan keluarga sendiri atau orang lain dalam jumlah yang tidak terbatas. Virtual synchronous adalah proses belajar mengajar yang dilakukan dengan tatap muka pada dunia maya dalam waktu yang bersamaan namun terjadi pada tempat yang berbeda (Dwiyanto, 2020). Kelebiahan dari strategi ini adalah seluruh umat muslim dunia dapat dengan mudah mengakses dan mengikuti dakwah yang diselenggarakan oleh individu atau organisasi atau komunitas dakwah. Sedangkan kekurangan dari startegi ini adalah orang atau mad'u yang belum memahami dan tidak bisa menggunakan perangkat IT dan sosial media tidak dapat mengikuti dakwah dengan sangat baik.

\section{E. Simpulan}

Strategi dakwah di era new normal diartikan sebagai cara yang akan digunakan oleh seorang da'i dalam menyiarkan kebaikan dan ajaran Islam kepada mad'u di masa new normal nanti. Tahapan dalam perumusan startegi dakwah dapat dilakukan melalui beberapa tahap, pertama analisis lingkungan dakwah yaitu analisis yang dilakukan terhadap lingkungan internal da'i dengan mengalisis keberadaan sumber daya yang dimiliki da'i untuk merumuskan startegi dakwah, dan analisis lingkungan eksternal yaitu dengan mengaalisis masalah atau isu yang terjadi di lingkungan eksternal yaitu tentang penyebaran virus Covid-19 di lingkungan masyarakat. Kedua perumusan strategi yaitu dengan mengumpulkan berbagai startegi dakwah yang "mungkin" akan digunakan di era new normal. Ketiga pemilihan strategi yaitu tahap memilih dan memutusakan strategi yang akan digunakan di era new normal. Keempat penggunaan startegi merupakan tahap memanfaatkan startegi pilihan untuk kegiatan dakwah. Dan kelima evaluasi strategi merupakan kegiatan menilai strategi dakwah yang telah digunakan. Startegi dakwah yang dapat digunakan di era normal oleh da'i antara lain: pertama dengan pendekatan keluarga yaitu dakwah yang dilakukan dalam lingkungan keluarga dengan tetap mematuhi protokol kesehatan dari pemerintah, kedua dengan tatap muka, yaitu suatu startegi dengan melakukan pertemuan langsung dengan mad'u dengan memperhatikan protokol kesehatan dari pemerintah, dan ketiga dengan memanfaatkan media sosial, yaitu dakwah yang dilakukan dengan menggunakan media sosial seperti whtasapp, Instagram, youtube, dan lain sebagainya sebagai sarana utama dalam menyiarkan ajaran agama Islam dan untuk mengurasi kontak langsung dengan orang lain.

\section{Daftar Pustaka}

Abzar, M. (2015). Strategi Dakwah Masa Kini (Beberapa Langkah Strategis Pemecahan Problematika Dakwah). Lentera, 17(1), 37-52.

Ahmadi, Khoiru, Amri, Sofan, \& Elisah, Tatik et.al. (2011). Strategi Pembelajaran Sekolah Terpadu. Jakarta: Prestasi Pustaka. 
Ajibroto, K., Keizer, H. De, \& Pringgabayu, D. (2018). Analisis Lingkungan Strategis Untuk Meningkatkan Kompetitifitas Produk Perbankan. JRMSI - Jurnal Riset Manajemen Sains Indonesia, 9(1), 56-71. doi: 10.21009/jrmsi.009.1.04.

Aldi, B. E. (2015). Upaya Generalisasi Konsep Manajemen Strategik. Jurnal ilmu ekonomi \& sosial, VI(2), 56-72.

Aminudin. (2016). Konsep Dasar Dakwah. Al-Munzir, 9(1), 29-46.

Arwildayanto, Suking, Arifin, \& Sumar, Warni Tune. (2018). Analsisi Kebijakan Pendidikan: Kajian Teoretis, Eksploratif, Dan Aplikatif. Bandung: Cendekia Press.

Anggara, Sahya. (2014). Kebijakan Publik. Bandung: CV. Pustaka Setia.

Baidowi, A. (2020). The Evaluation of Online and Face to Face Physical Education Learning Policy at Elementary School Level. Tegar: Journal of Teaching Physical Education in Elementary School, 4(1), 35-44. doi: DOI: https://doi.org/10.17509/tegar.v4i1.28211.

Chaniago, S. A. (2014). Perumusan Manajemen Strategi Pemberdayaan Zakat. Journal Jurnal Hukum Islam (JHI), 12(1), 87-101.

Churri, M. A., \& Agung, Y. A. (2013). Dasar Kompetensi Kejuruan Teknik Audio Video Untuk SMK Negeri 7 Surabaya. Jurnal Pendidikan Teknik Elektro, 2(2), 803-809.

Dwiyanto, H. (2020). Menyiapkan Pembelajaran dalam Memasuki "New Normal " dengan Blended Learning. Pengembang Teknologi Pembelajaran LPMP Lampung, 1-9.

Effendi, M. R. (2021). Relasi Agama dan Masyarakat; Studi Tentang Interaksi Masyarakat Bandung Barat dan Jamaah Tabligh. Hayula, 5(1), 1-24. https://doi.org/https://doi.org/10.21009/hayula.005.1

Effendi, M. R., Kahmad, D., Solihin, M., \& Wibisono, M. Y. (2021). Relasi Agama dan Masyarakat: Studi Tentang Interaksi Masyarakat Bandung Barat dan Jamaah Tabligh. Hayula: Indonesian Journal of Multidisciplinary Islamic Studies, 5(1), 1-24.

Fatwa Majelis Ulama Indionesia Nomor 14 Tahun 2020 tentang Penyelenggaraan Ibadah Dalam Situasi Terjadi Wabah Covid-19.

Hasan, Mohammad. (2013). Metodologi Pengembangan Ilmu Dakwah (R. Adawiyah, ed.). Surabaya: Pena Salsabila.

Mahnun, N. (2012). Media Pembelajaran (Kajian terhadap Langkah-langkah Pemilihan Media dan Implementasinya dalam Pembelajaran). An-Nida': Jurnal Pemikiran Islam, 37(1), 27-35.

Miharja, S., \& Syamsuddin. (2018). Dakwah Pemberdayaan Partisipasi Keluarga. Anida (Aktualisasi Nuansa Ilmu Dakwah), 18(1), 1-20. doi: 10.15575/anida.v18i1.5039.

Mulawarman, M., \& Nurfitri, A. D. (2017). Perilaku Pengguna Media Sosial beserta Implikasinya Ditinjau dari Perspektif Psikologi Sosial Terapan. Buletin Psikologi, 25(1), 36-44. doi: 10.22146/buletinpsikologi.22759.

Mutiawati, I. (2018). Dakwah di Media Sosial (Studi Fenomenologi Dakwah di Instagram) Jurnal Muttaqien: e-ISSN : 2723-5963| 73 
(Universitas Islam Negeri Walisongo; Vol. 2). Universitas Islam Negeri Walisongo. Retrieved from http://eprints.walisongo.ac.id/9496/1/SKRIPSI LENGKAP.pdf.

Nurpratiwi, M. R. E. dan S. (2021). Hubungan Keberagamaan dan Perilaku Altruistik Mahasiswa. Al-Afkar, 4(1), 83-97. https://doi.org/https://doi.org/10.31943/afkarjournal.v4i1.181

Effendi, M. R., \& Nurpratiwi, S. (2021). H Hubungan Keberagamaan dan Perilaku Altruistik Mahasiswa. al-Afkar, Journal For Islamic Studies, 4(1).

Pane, A., \& Dasopang, M. D. (2017). Belajar Dan Pembelajaran. Fitrab:Jurnal Kajian Ilmu-Imu Keislaman, 3(2), 333. doi: 10.24952/fitrah.v3i2.945.

Ramadhani, F., Nahar, S., \& Syaukani. (2018). Konsep Evaluasi Pendidikan Dalam Al-Qur'an Surah Az-Zalzalah Ayat 7-8 Al-Baqarah Ayat 31-34. Edu Religia, 2(2), 183-196.

Rangkuti, Freddy. (2013). Teknik Membedah Kasus Bisnis: Analisis SWOT. Jakarta: PT. Gramedia Pustaka Utama.

Risdiana, A. (2014). Transformasi Peran Da’i dalam Menjawab Peluang dan Tantangan (Studi Terhadap Manajemen SDM). Jurnal Dakwah, 15(2), 433-451. Retrieved from http://ejournal.uin-suka.ac.id/dakwah/jurnaldakwah/article/view/315.

Sari, A. C., Hartina, R., Awalia, R., Irianti, H., \& Ainun, N. (2019). Komunikasi dan media sosial. (January 2019). Retrieved from https://www.researchgate.net/publication/329998890_KOMUNIKASI_DAN_ME DIA_SOSIAL.

Sawaluddin. (2018). Konsep Evaluasi Dalam Pembelajaran Pendidikan Islam. Jurnal AlThariqah, 3(1), 39-53.

Silitonga, Y., \& Eminency, D. (2012). Analisa Perbandingan Kualitas Belajar-Mengajar Antara Metode Face to Face dan Video Conference. Jurnal Sistem Informasi (JSI), 4(2), 477-487. Retrieved from https://ejournal.unsri.ac.id/index.php/jsi/article/view/1270/439.

Suharno, S., Sudibyo, C., P, B., \& S., E. (2014). Model Formulasi Strategi Peningkatan Mutu Dan Relevansi Pendidikan Teknologi Dan Kejuruan. Innovation of Vocational Technology Education, 10(2), 131-140. doi: 10.17509/invotec.v10i2.4854.

Tafonao, T. (2018). Peranan Media Pembelajaran Dalam Meningkatkan Minat Belajar Mahsiswa. Jurnal Komunikasi Pendidikan, 2(2), 103-114.

Undang-Undang Republik Indonesia Nomor 18 Tahun 2002 tentang Sistem Nasional Penelitian, Pengembangan, dan Penerapan Ilmu Pengetahuan dan Teknologi. 